\title{
MEDICINE
}

\section{INTERDISCIPLINARY APPROACH TOWARDS THE DIAGNOSTICS OF STRESS-INDUCED DISORDERS OF THE REPRODUCTIVE FUNCTION OF WOMEN}

\author{
Goncharenko V.N. \\ "Feofaniya" Clinical Hospital, Kyiv \\ DOI: https://doi.org/ 10.31435/rsglobal_ws/30122018/6264
}

\section{ARTICLE INFO}

Received: 14 October 2018

Accepted: 26 December 2018

Published: 30 December 2018

\section{KEYWORDS}

Amenorrhea,

stress,

electroencephalography,

reactive anxiety,

personal anxiety,

hyperprolactinemia,

hypercortisolemia.

\begin{abstract}
The paper presents the results of a survey of 54 women with psychogenic amenorrhea. There are options of hormonal disorders in this disease, presents an analysis of electroencephalography and the study of individual and reactive anxiety in patients with psychogenic amenorrhea. The presence of three pathogenetic variants of hormonal disorder was discovered that has served criterion of the proposed differential pathogenetic treatment.
\end{abstract}

Citation: Goncharenko V. N. (2018) Interdisciplinary Approach Towards the Diagnostics of StressInduced Disorders of the Reproductive Function of Women. World Science. 12(40), Vol.1. doi: 10.31435/rsglobal_ws/30122018/6264

Copyright: (C) 2018 Goncharenko V. N. This is an open-access article distributed under the terms of the Creative Commons Attribution License (CC BY). The use, distribution or reproduction in other forums is permitted, provided the original author(s) or licensor are credited and that the original publication in this journal is cited, in accordance with accepted academic practice. No use, distribution or reproduction is permitted which does not comply with these terms.

Nowadays, various aspects of the stress response in the body continue to be of great interest to physiologists, cardiologists, psych neurologists, endocrinologists, gynecologists, that determine the relevance and interdisciplinary nature of the problem. The modern tense rhythm of life contributes to a sharp increase in the psycho-emotional load on a person, which are associated with the process of perception and analysis of information, the complexity of decision-making, violation of the regime of work and rest $[6,20,21]$.

According to the WHO, every fourth person on Earth has stress-induced health problems and according to forecasts this pathology will have occupied the second place in frequency, second only to cardiovascular diseases by $2020[11,5]$.

As many thousands of years ago, our body responds to complex life situations by the instantaneous reaction of the nervous system with the inclusion of the mental, hormonal and reproductive spheres. The ability of the regulatory systems to mobilize the necessary functional reserves, to provide the physiological protection of the body against stress can save homeostasis and maintain the state of adaptation. The works of domestic and foreign scientists have proved that stress disrupts various physiological functions of the organism, including the reproductive system of the body [8].

The female reproductive system, being the fastest-transforming biological object, immediately responds to adverse external and internal factors by the appearance of new adaptation reactions, which acquire under the certain conditions the properties of the pathological process [13].

Strengthening the aggressiveness of the human habitat, the need to adapt to increased intellectual and psychological stresses, hypodynamia, and deterioration of the ecological situation determine the topicality of the problem of neuroendocrine disorders in the pathogenesis of diseases of 
the reproductive system. In this case, the most frequent cause of hypothalamic dysfunction is precisely psycho-emotional stress [12].

Moreover, in connection with the increase of stress on women in modern society, the number of stress-induced disorders of this system increases every year, which makes this a problem of social importance. The study of the influence of emotional stress, development of methods of diagnosis and treatment of pathology determined by stress, including female reproductive system is a whole trend of modern medical science $[12,15,16]$.

Constitutional-typological peculiarities of the central nervous system, individual peculiarities, and psycho-emotional factors can be used in varying degrees in violation of integrative cerebral systems of the supergemetric level, as a result of which manifestations of hormonal and somatic disorders $[1,3]$. The variety of psychogenic influences in modern conditions is accompanied by the growth of affective disorders among women and requires the widespread use of clinical and psychological methods for determining the mechanisms of central disorders in gynecological diseases. Psychogenic amenorrhea (PA), which manifests itself as a lack of menstruation for six or more months under the influence of various mental influences - severe stress and neuropsychic stress [4], is one of the manifestations of stress-dependent menstrual cycle disorder.

Considering the pathogenic mechanisms of this pathology occurrence, it is important to note that in conditions of stress, the cerebral cortex tries to compensate the severity of its effects by secreting the structures of the brain of its own (endogenous) opiates - substances that alleviate the stressful effects [19]. The selection of opiates causes cascade changes in hormonal relationships in the hypothalamic-pituitary-adrenal system. There is an increase in the activity of the opioidergic system and an increase in the synthesis of endorphins, an increase in the synthesis of corticotropin releasing of the hormone, which causes activation of the adrenal cortex with an increase in the synthesis and secretion of cortisol. As a result, it inhibits the secretion of gonadotropin-releasing hormone, decreases luteinizing and follicle-stimulating hormones [13, 14].

One of the pathogenic manifestations of the stress response of the female body is a functional hyperprolactinemia, which enhances hypothalamic-pituitary dysfunction, reduces the synthesis and secretion of $\mathrm{GnRh}$, breaking the sensitivity of the hypothalamus to estrogens reduces the secretion of progesterone luteum contributes to the suppression of reproductive function in women $[1,17,18]$.

Pathogenic mechanisms of stress influence on reproductive health and fertility of a woman are multilevel and cascading; therefore, the development of new approaches to the treatment of this pathology is an actual direction of modern gynecology.

The aim of our study was to determine the pathophysiological mechanisms of menstrual irregularity from the standpoint of an interdisciplinary approach.

Materials and methods. The study included 54 women aged 19 to 37 years, who were treated at the "Feofania" CH women's health Center ". Criteria for selection of case patients were the following: after stressful menstrual function disorder of the secondary amenorrhea type on the background of low or normal levels of gonadotropins.

The exclusion criteria were the following: the presence of thyroid gland disease, the hormone producing tumors, the uterine form of amenorrhea, women with a body weight deficit (body mass index less than 18.5), and obesity (body mass index greater than 30). The control group consisted of 25 practically healthy patients aged 18 to 35 years.

All patients were examined, which included the following: the anamnesis data studying, measuring anthropometric data, general clinical, laboratory, and ultrasound examination of the pelvic organs. Also, the levels of follicle stimulating hormone (FSH), luteinizing hormone (LH) of hormones, estradiol (E), progesterone (P), prolactin (Prl), dihydroepiandrosterone sulfate (DHEAS), cortisol (C) were determined in the plasma by the immune enzyme method. Taking into account the stress-induced nature of the violation of the menstrual function of the patients, they were consulted by a neuropathologist, a psychotherapist with a profile test. The central nervous system examination was performed with the following being involved: electroencephalographic examination (EEG) using the Nicolet system (USA), MRI of the brain.

The scale of individual and reactive anxiety Spielberg-Hanin was used to determine the level of alarm and anxiety of the patients used. When analyzing the results of the study used the appropriate key to the study.

Data processing was performed by means of SPSS 11.5 Windows. The assessment of the reliability of the differences in the mean and relative variables was carried out by means of standard methods of variation statistics. 
Results and their discussion. Study of the hormonal profile peculiarities of patients with PA showed the existence of several variants of the violation of hormonal relationships, which allowed the distribution of patients into 3 main groups of three groups.

It was found that for $24(44.4 \%)$ patients (group 1); the level of prolactin exceeded the control group's performance by 3.6 times, and with cortisol levels corresponding the norm. LH and FSH indexes met the norm but were lower than the control group (Figure 1).

Isolated increase of cortisol in the blood against the background normative values of prolactin was found among $17(31.5 \%$ ) women (2 group of patients), with the level of LH and FSH corresponding the norm, as for group 1 patients, but was lower compared with the control groups.

Combined increase of prolactin and cortisol levels was observed among $13(24.1 \%)$ patients with PA; this category of patients was group3 of our study. The prolactin level in this group exceeded the control group's indexed by 3.1 times, cortisol by 4.3 times, the levels of LH and FSH were lower in the control group by 2.1 and 1.8 times, respectively.

The study of levels of estradiol (E2) group showed a 1,5-1,6 times' decrease in the level of this hormone comparison to the control group. A similar tendency was observed while assessing the level of progesterone, there was a $1.3-1.6$ times decrease of its level among patients with PA compared to the control group.

Table 1. Hormone profile indexes for the examined patients before treatment.

\begin{tabular}{|l|c|c|c|c|}
\hline \multirow{2}{*}{$\begin{array}{l}\text { index } \\
\text { (units of measurement) }\end{array}$} & \multicolumn{3}{|c|}{ Main groups } & \multirow{2}{*}{$\begin{array}{c}\text { Control group } \\
(\mathrm{n}=25)\end{array}$} \\
\cline { 2 - 4 } & $\begin{array}{c}1-\mathrm{a} \\
(\mathrm{n}=24)\end{array}$ & $\begin{array}{c}2-\mathrm{a} \\
(\mathrm{n}=17)\end{array}$ & $\begin{array}{c}3-я \\
(\mathrm{n}=13)\end{array}$ & \\
\hline Prl (ng/ml) & $61,7 \pm 6,2^{*}$ & $20,8 \pm 2,2$ & $54,2 \pm 5,8^{*}$ & $17,4 \pm 1,8$ \\
\hline DHEAS (mcg/dl) & $162,9 \pm 8,4^{*}$ & $154,2 \pm 6,8$ & $182,7 \pm 9,1^{*}$ & $143,8 \pm 7,2$ \\
\hline LH (ivf/l) & $3,1 \pm 0,2^{*}$ & $3,4 \pm 0,4^{*}$ & $4,2 \pm 0,5^{*}$ & $8,7 \pm 0,5$ \\
\hline FSH (ivf/l) & $5,3 \pm 0,4^{*}$ & $6,8 \pm 0,3^{*}$ & $5,1 \pm 0,3^{*}$ & $9,3 \pm 0,6$ \\
\hline $\mathrm{C} \mathrm{(mcg/dl)}$ & $15,6 \pm 1,9$ & $36,2 \pm 2,9^{*}$ & $51,7 \pm 3,4^{*}$ & $12,4 \pm 1,9$ \\
\hline E2 (pg/ml) & $54,2 \pm 5,2^{*}$ & $61,6 \pm 4,7^{*}$ & $51,5 \pm 6,1^{*}$ & $87,65 \pm 7,3$ \\
\hline $\begin{array}{l}\text { Thyrotropic hormone } \\
\text { (mcU/ml) }\end{array}$ & $2,1 \pm 0,1$ & $1,7 \pm 0,2$ & $1,6 \pm 0,2$ & $1,7 \pm 0,3$ \\
\hline Progesterone (ng/ml) & $0,9 \pm 0,08^{*}$ & $1,3 \pm 0,09^{*}$ & $0,8 \pm 0,1^{*}$ & $3,2 \pm 0,1$ \\
\hline
\end{tabular}

Note* - the indexes difference is valid (compared to the control group) $(\mathrm{p}<0,05)$

Identified features of hormonal hemostasis disorders among women with PA give grounds to think that the decrease in the level of LH and FSH with the background increase of cortisol and prolactin is a result of the increased activity opiodergic and dopaminergic neurons.

Taking into account the fact that disorder of hypothalamic and extrapolatory brain structures is important for the pathogenesis of PA, further researches of central nervous system function have been conducted.

The EEG results, it was conducted in the calm state of patients, showed the presence of nonspecific signs of brainstem structures activation among representatives of three main groups. The patients with PA were characterized by the epileptoid activity signs - $3(12,5 \%)$ women of the first group, $1(5,8 \%)$ of observations of the second group. As for the third main and control groups the given EEG feature was not observed.

The alpha-rhythm index and an amplitude decrease were observed among $18(75 \%)$ women of group 1, among $15(88,2 \%)$ patients of group 2 and $11(84,6 \%)$ women for group 3 ; at the same time, the similar alpha rhythm's nature was observed among $5(20 \%)$ women of the control group. The amplitude decrease and alpha-rhythm index were observed among $18(75 \%)$ women of first group 1 , $15(88,2 \%)$ patients of group 2 and among $11(84,6 \%)$ of group 3, while among $5(20 \%)$ women in the control group a similar nature of the alpha rhythm was also observed. The "flashing" high amplitude polymorphic activity domination including alpha - and theta - rhythm was observed among $6(25 \%)$ patients of first group 1, among $7(41,1 \%)$ women of group 2 and among 4 (30.7 percent) group 3. As for the control group, the above-mentioned EEG symptom was found among 1 (4\%) woman. The violation of the regularity and uniformity of the zonal distribution of the basic cortical rhythm was observed among $21(87,5 \%)$ women of group 1, among $16(94,1 \%)$ women of group 2 and $10(76,9 \%)$ women of group 3, while as for the control group this index stood for 4 (16\%). Thus, the $4.7-5.8$ times' increase in the percentage of patients with this EEG symptom PA with the background PA was observed. 
Table 2. EEG profile indexes for the examined patients before treatment

\begin{tabular}{|c|c|c|c|c|}
\hline \multirow[b]{2}{*}{ Index } & \multicolumn{3}{|c|}{ Main groups } & \multirow{2}{*}{$\begin{array}{l}\text { Control group } \\
\quad(n=25)\end{array}$} \\
\hline & $\begin{array}{c}1-\mathrm{a} \\
(\mathrm{n}=24)\end{array}$ & $\begin{array}{c}2-\mathrm{a} \\
(\mathrm{n}=17)\end{array}$ & $\begin{array}{c}3-\mathrm{a} \\
(\mathrm{n}=13)\end{array}$ & \\
\hline Epileptoid activity signs & $\begin{array}{c}3 * \\
(12,5 \%)\end{array}$ & $\begin{array}{c}1 * \\
(5,8 \%)\end{array}$ & 0 & 0 \\
\hline $\begin{array}{l}\text { The decrease in the amplitude } \\
\text { and alpha-rhythm index }\end{array}$ & $\begin{array}{l}18 * \\
(75 \%)\end{array}$ & $\begin{array}{c}15^{*} \\
(88,2 \%)\end{array}$ & $\begin{array}{c}11 * \\
(84,6 \%)\end{array}$ & $\begin{array}{c}5 \\
(20 \%) \\
\end{array}$ \\
\hline $\begin{array}{l}\text { The "flashing" high ampliture } \\
\text { polymorphic activity } \\
\text { domination including alpha - } \\
\text { and theta - rhythm }\end{array}$ & $\begin{array}{c}6^{*} \\
(25 \%)\end{array}$ & $\begin{array}{c}7^{*} \\
(41,1 \%)\end{array}$ & $\begin{array}{c}4^{*} \\
(30,7 \%)\end{array}$ & $\begin{array}{c}1 \\
(4 \%)\end{array}$ \\
\hline $\begin{array}{l}\text { The violation of the regularity } \\
\text { and uniformity of the zonal } \\
\text { distribution of the basic cortical } \\
\text { rhythm }\end{array}$ & $\begin{array}{c}21 * \\
(87,5 \%)\end{array}$ & $\begin{array}{c}16^{*} \\
(94,1 \%)\end{array}$ & $\begin{array}{c}10 * \\
(76,9 \%)\end{array}$ & $\begin{array}{c}4 \\
(16 \%)\end{array}$ \\
\hline $\begin{array}{l}\text { Extend of the range of reaction } \\
\text { of adopting the rhythm by } \\
\text { means of photo stimulation }\end{array}$ & $\begin{array}{c}22 * \\
(91,6 \%)\end{array}$ & $\begin{array}{c}15^{*} \\
(88,2 \%)\end{array}$ & $\begin{array}{c}12 * \\
(92,3 \%)\end{array}$ & 0 \\
\hline $\begin{array}{l}\text { Signs of the cerebral } \\
\text { hemisphere asymmetry }\end{array}$ & $\begin{array}{c}24 * \\
(100 \%)\end{array}$ & $\begin{array}{c}17 * \\
(100 \%)\end{array}$ & $\begin{array}{l}13 * \\
(100 \%)\end{array}$ & $\begin{array}{c}4 \\
(16 \%)\end{array}$ \\
\hline
\end{tabular}

Note* - the indexes difference is valid (compared to the control group) $(p<0,05)$

A similar tendency was observed in the detection intersphere asymmetry - the growth in the number of patients up to 3 to 6 times in three main groups in comparison to the control group, which was a marker for the increased mental and emotional stress. The data obtained indicate that in case of PA the EEG signs of activation of stem structures of the brain, the signs of the cerebral hemisphere asymmetry with the activity of the right hemisphere were observed.

The results of psychological testing with the Spielberg-Hanin scale being applied showed a high level of personal and reactive anxiety in the basic groups compared to the control group (figure 1).

Pathopsychological changes manifest themselves in the form of increasing sanitation, strengthening of individual constitutional anxiety, stableness dysthymic reactions, reducing the selfawareness of one's state of health. The high frequencies of such qualities as jealousy, anxiety, restraint were observed. The assessment in points of reactive and personal anxiety showed a $1.5-2.4$ times' increase of the given indicator in three main groups compared to the control group.

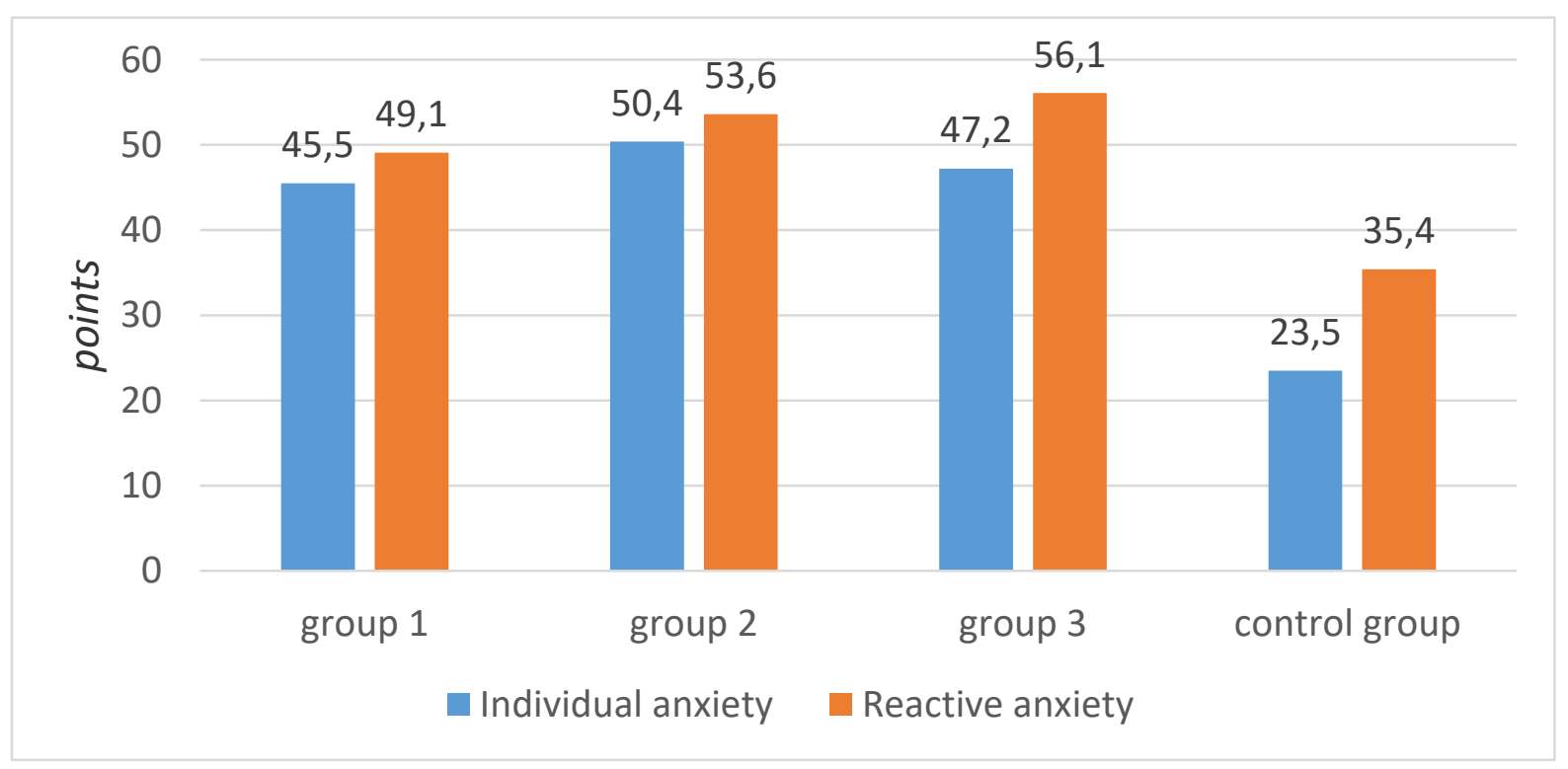

Fig. 1. Psychological characteristics of the examined patients on the Spilbega-Hanin scale, points. 
Conclusions. Thus, the study conducted indicated the presence of three pathogenic variants of hormonal imbalance among women with PA that may serve a criterion for further selection of differential treatment.

Increase of the prolactin level or combined with increased levels of cortisol determines the need for a thorough examination with the aim of detecting the genesis of hyperprolactinemia.

Specific features of pathogenesis psychogenic amenorrhea, the complexity of the neuroendocrine and hormonal disorders, indicate the need for an interdisciplinary approach in the examination, treatment and rehabilitation of this category of patients, with involvement of adjacent neurologist and psychotherapist experts.

\section{REFERENCES}

1. Бенюк В. О. Современные детерминанты патогенеза гиперпластических процессов эндометрия /Бенюк В. О, Гончаренко В. М., Никонюк Т. Р.// Здоровье женщины. - 2016. - №5. - С. 89-94.

2. Бенюк В. А., Венцковская И. Б., Жук С.И., Гончаренко В. Н. и соавт/ Амбулаторнополиклиническая помощь в гинекологии / Довідник. - К.: «Здоров’я України», 2010. - 462 с.

3. Бенюк В. А., Гончаренко В. Н., Гирина О. Н., Усевич И. А. и соавт. Справочник семейного врача по акушерству и гинекологии // Справочник врача. - К.: ТОВ «Доктор-Медиа», 2012. - 622 с.

4. Бенюк В. А., Гончаренко В. Н., Забудский А. В., Кувита Ю. В. и соавт. Внутриматочная патология / Довідник «Гинеколог». - К.: «Здоров’я України», 2013. - 206 с.

5. Бенюк В. О., Макаренко М. В., Гончаренко В. Н., Гичка Н.М. и соавт. Алгоритмы в акушерстве и гинекологии / Справочник врача. - К.: ТОВ «Доктор-Медиа», 2016. - 510 с.

6. Венцковская И. Б., Загородняя А. С. Стресс-индуцированные нарушения репродуктивной и сексуальной функции // Репродуктивное здоровье. Восточная Европа. - 2013. - №2. - С. 113-119

7. Дубоссарская 3. М. Теория и практика гинекологической эндокринологии. Днепропетровск: ЧП «Лира ЛТД», 2005: 412.

8. Леонтьева Е. С. Патологическая физиология эндокринной системы: методическое пособие / Е. С. Леонтьева, Н. А. Степанова. - Минск: БГМУ, 2009. - 36 с.

9. Менделевич, В.Д. Клиническая и медицинская психология: практ. рук. / В.Д. Менделевич. - М.: МЕДпресс, 2001. - 592 с.

10. Морозов, В.Н.К современной трактовке механизмов стресса / В.Н. Морозов, А.А. Хадарцев // BНMT. - 2010. - № 1 .

11. Никонов В. В. Стресс. Современный патофизиологический подход к лечению / В.В. Никонов - М., 2002. $-314 \mathrm{c}$.

12. Пшеничникова М.Г. Феномен стресса. Эмоциональный стресс и его роль в патологии / М.Г. Пшеничникова // Патол. физиол. и эксперим. терапия. - 2000. - №2-4, 2002. - №1-3.

13. Судаков К.В. Психоэмоциональный стресс: профилактика и реабилитация. Тер. архив. - 1997. - Т. 69. - №1. - С. 70-74.

14. Татарчук Т. Ф., Булавенко О.В., Тутченко Т.Н. Оптимизация методов лечения недостаточности лютеиновой фазы у женщин репродуктивного возраста на фоне гиперпролактинемии. Здоровье женщины, -2008, 2(34): с.72-77.

15. Татарчук Т. Ф. Стресс и репродуктивная функция женщины // Междунар. эндокринол. журн. - № 3 (5). $-2006 .-$ C. $2-9$

16. Татарчук Т. Ф., Ефименко О. А., Тутченко Т. Н. Стресс и инволюция репродуктивной системы женщины. Репродутивное здоровье женщины, -2007, 2(34): с.72-77.

17. Татарчук Т. Ф. Шкала оценки переживания стресса Perceived Stress Scale (PSS): основные этапы адаптации для женского населения Украины // Зб.наук.праць Асоціації акушерів-гінекологів України. - К.: Інтермед, 2009. - С. 606-613.

18. Татарчук Т. Ф., Ефименко О.А. Современный менеджмент гиперпролактинемии // Здоровье женщины. - 2009. - № 9 (45). - С. 33-37.

19. Татарчук Т. Ф., Венцковская И.Б., Ефименко О.А. Гиперпролактинемия в практике врача гинеколога // Міжнародний ендокринологічний журнал. - 2007. - № 1 (7). - С. 40-48.

20. Chatterjee A. How stress affects female reproduction: An over! view / A. Chatterjee, R. Chatterjee // Biomedical Research. -2009. - Vol. 20 (2). - P. 79-83.

21. Aftanas L. I. Neurophysiological correlates of induced discrete emotions in humans: an individually oriented analysis / L. I. Aftanas, N. V. Reva, L. N. Savotina, V. P. Maknev // Neuroscience and Behavioral Physiology. - 2006. -Vol. 36(2). - PP. 119-130

22. Salam Ranabir and K. Reetu. Stress and hormones PMCID: PMC3079864 Indian J Endokrinol Metab. 2011 Jan-Mar; 15(1): 18-22. 